ARTICLES

\title{
LES CONVICTIONS POLITIQUES DE TOLAND
}

\author{
Paulette CARRIVE
}

RésumE : Si les sympathies de Toland pour le régime "républicain 》 (en anglais de l'époque, « commonwealthman » pour le substantif, « republican » pour l'adjectif ou le substantif) ne sont guère mises en doute aujourd'hui, encore faut-il s'entendre sur ce que signifie ce terme de « républicain ». Les éditions que donna Toland d'ouvrages dont les thèses antiabsolutistes étaient connues de tous et les préfaces dont il les munit sont un argument sérieux en faveur d'un Toland « républicain ». Il faut cependant mettre en lumière les différents sens que Toland accepterait ou refuserait de donner à la notion de «république». De nombreuses thèses de l'auteur sont communes aux whigs et aux républicains, et pourtant il manifeste sa méfiance à l'égard des partis. Ce qui est certain, c'est que Toland défend vivement les libertés - liberté de conscience, liberté de la presse, liberté du commerce - et aussi l'idée d'équilibre tant à l'intérieur des divers pouvoirs de l'État que dans le concert des nations.

Mots clés : constitution, équilibre, liberté, partis, république.

SUMmaRY : That Toland leant towards a "republican " form of government is widely accepted nowadays, but the meaning of that word "republican " needs defining. The editions which Toland grave of works whose anti-absolutist theses were known by all and the prefaces he added to them are a serious argument in favour of his " republicanism ". But it is necessary to point out the different senses in which Toland accepts or refuses the notion of a "Republic " or a "Commonwealth ". Many of his convictions were shared by whigs and by republicans, yet he distrusted all political parties. What is certain is that Toland was a passionate advocate of freedom - freedom of conscience, freedom of the press, freedom of trade - as well as of the idea of balance both within the powers of government and within the concert of nations.

Keywords : constitution, balance, freedom, political parties, republicanism.

Revue de synthèse : $4^{e}$ S. Nos 2-3, avr.-sept. 1995, p. 231-257. 
ZuSAMmEnfassung : Daß Toland eine "republikanische " Regierungsform bevorzugte, wird heutzutage allgemein anerkannt. Man muß jedoch den Begriff "Republikaner" klar definieren. Was Toland unter "republikanisch" verstand, geht besonders deutlich aus den weithin bekannten, von ihm herausgegebenen antiabsolutistischen Werken hervor, sowie aus den Vorworten, die er ihnen voranstellte.

Dabei muß man zwischen den verschiedenen Bedeutungen von "Republik" unterscheiden, die Toland akzeptiert oder abgelehnt hätte. Obwohl viele seiner Ideen von Whigs und Republikanern geteilt wurden, mißtraute Toland allen politischen Parteien. Sicher ist, daß Toland ein leidenschaftlich überzeugter Befürworter der Freiheit war, womit Gewissensfreiheit, Pressefreiheit und Freiheit des Handels gemeint sind. Dazu kam die Idee des Gleichgewichts innerhalb der Machtkomplexe in einem Staat und bei der Zusammenarbeit verschiedener Staaten.

Stichwörter : Verfassung, Gleichgewicht, Freiheit, Parteien, Republik.

Paulette CARrIve, née en 1932, est ancienne élève de l'École normale supérieure de Sèvres. Elle est professeur de philosophie à l'université Paris I-Panthéon Sorbonne et spécialiste de la philosophie britannique de la fin du Xvi siècle à la première moitié du xvin siècle.

Adresse : U.F.R. de philosophie, 17 rue de la Sorbonne, 75231 Paris Cedex 05. 
Les sympathies de Toland pour le régime républicain ne sont guère mises en doute aujourd'hui. Encore faut-il définir exactement ce que Toland lui-même entendait par républicain («commonwealthman" mais aussi « republican »). Sa définition est pour le moins prudente. Ses sympathies whigs, plus tardives, sont aussi moins ambiguës.

La manifestation la plus évidente de ses sympathies républicaines est la publication d'œuvres d'auteurs que l'on peut, en simplifiant on le verra, classer parmi les républicains. Le premier en date est Milton. Même si, dans la «Dédicace » à Oceana de James Harrington en 1700, Toland dit qu'il a bien écrit l'histoire de la vie de Milton, mais qu'il n'a pas participé à l'édition de ses œuvres, "or otherwise his logic, his grammar and the like had not increas'd the bulk or price of his other useful pieces », sa préface, Life of Milton ${ }^{1}$, très nuancée d'ailleurs, est un signe évident de son intérêt pour l'auteur d'Areopagitica et de Pro Populo Anglicano Defensio; il signale, à propos de ce dernier texte, l'admiration de Bayle. La mention de l'attachement de Milton pour «the Good Old Cause ${ }^{2}$ est aussi très significative.

Mais les réserves de Toland à l'égard de Milton ne sont pas moins significatives. On connaît - et on retrouvera - la sévérité de Toland à l'égard de Cromwell. Or Milton fut son «Latin Secretary", et Toland rappelle le souhait, à ses yeux hypocrite, qu'exprima Cromwell et que Milton prit au sérieux, " to extinguish the numerous factions of the State and to settle such a perfect form of government wherein no single person should injoy any power above or beside the laws ». Surtout, parlant du texte écrit par Milton à la veille de la Restauration, The Ready and Easy Way to Establish a Free Commonwealth (1660), Toland dit ceci : "In this book he delivers the model of a Commonwealth, well suited perhaps to the circumstances of that time, but inferior in all respects to Harrington's Oceana, which, for the

1. The Life of Milton (cité par la suite comme $L . M$.) en préface à $A$ Complete Collection of the Historical, Political [... J Works of John Milton, Amsterdam, 1698. Cette Vie est aussi éditée avec Amyntor, or a Defence of Milton's Life (cité par la suite comme Am.), Londres, 1699. Bayle, qui ne savait pas l'anglais, a fait traduire en latin des extraits de cette vie pour son Dictionnaire (article « Milton »). Pour mon propos, les œuvres importantes de John Mitron sont Areopagitica, Londres, 1644, Pro Populo Anglicano Defensio, Londres, 1651, Second Defence of the People of England, Londres, 1654, The Ready and Easy Way to Establish a Free Commonwealth, Londres, 1660. Toland a édité Oceana de James Harringron, Londres, 1700; la « Dédicace » et The Life of Harrington au début de cet ouvrage sont cités par la suite L.H.

2. «La bonne vieille cause » est un leitmotiv de la pensée républicaine en Angleterre. En 1654, dans une Humble Petition à Cromwell, des colonels ont rappelé l'époque des années 1648 où l'armée se sentait engagée à assurer la tenue de Parlements constants, à protéger la religion établie, les lois et les libertés du pays. 
practicableness, equality and completeness of it is the most perfect form of such a government that was ever delineated by any antient or modern pen.»

Enfin, il rend un vibrant hommage à Algernon Sidney ${ }^{3}$, et cela l'année même de la parution des Discourses Concerning Government; parlant des traités qui dénoncent les tyrans et les usurpateurs, il écrit : « witness the incomparable and golden Discourses of that heroic patron of liberty, Algernon Sidney. And indeed the best books we have on any subject are such as were oppos'd to the prevalency of the contrary opinion [...]; none can be so well furnish'd with arguments for a good cause, like such as were sufferers under a bad one."

Ce texte constitue de plus un indice sérieux en faveur de la thèse selon laquelle Toland a bien publié ces Discours, ou du moins qu'il en a écrit la Préface en 1698. Cette édition est souvent attribuée (en particulier par les catalogues de la Bibliothèque nationale et de la British Library) à Isaac Littlebury, républicain convaincu et traducteur d'Hérodote (à qui l'on a parfois attribué aussi l'édition, reconnue être de Toland, des Memoirs of E. Ludlow). Giancarlo Carabelli écrit dans Tolandiana ${ }^{4}$ que R. R. Evans, dans sa thèse John Toland's Pantheism (Mass., 1965), attribue sans preuve à Toland la préface des Discours. Or l'attribution de cette préface à Toland est attestée par Thomas Hollis ${ }^{5}$ dans son édition de 1763 des Discourses, et confirmée par G.W. Meadly ${ }^{6}$ et A. C. Ewald ${ }^{7}$. Dans une lettre à $\mathbf{M}^{* * *}$ du 26 juin 1705, Toland écrit: «Besides what I wrote myself I likewise publish'd the Lives and Works of Harrington and Milton, with some other authors; and though I protest not to agree with them in everything (especially in their democratical schemes of government) yet in general they

3. Voir Algernon STDNEY, Discourses Concerning Government, Londres, 1698, trad. franc., Discours sur le gouvernement, par P. A. SAMSON, 3 vol., la Haye, 1702, repr. en 1794 (mon édition de référence). La comparaison de Milton et de Sidney est souvent faite à cette époque, d'abord par Milton lui-même dans Second Defence of the People of England en 1654, et par Richard Baron, éditeur de Sidney (1751) dans sa préface à Eikonoklastes de Milton en 1756.

4. Voir Giancarlo Carabeld, Tolandiana. Materiali bibliografici, Florence, La Nuova Italia, 1975 , p. 378.

5. Th. Hollis (1720-1774), républicain passionné de liberté, vice-président de la Royal Society, partisan de l'indépendance américaine, consacra sa vie à faire connaître dans le monde entier les cuvres qui chantent la liberté. Voir William SHERLOCK, doyen de Saint-Paul, Cursory Remarks upon some Late Disloyal Proceedings, Londres, 1699, p. 6-7, accuse dès cette date Toland d'avoir pris une large part à la divulgation d'auteurs républicains, Harrington, Milton, et de " many other Discourses of other authors, as Ludlow's Letters, and Mr Sidney's Discourses of Government, all on the same subjects and tending to promote the design of lessening and reproaching monarchy".

6. Voir George Wilson Meadly, Memoirs of Algernon Sidney, Londres, 1813, p. 298.

7. Voir Alexander Charles Ewald, The Life of Sidney, Londres, 1873, t. I, p. 150, n. et t. II, p. $345, \mathrm{n}$. 
greatly contributed to beget in the minds of men, as the effect has shewn, an ardent love of liberty, and an extreme aversion to arbitrary power $\gg{ }^{8}$.

Sidney est-il visé ici ? Toland, dans The Art of Governing by Partys, cite «the great Colonel Sidney» qui, dans la $25^{\mathrm{e}}$ section de la seconde partie des Discourses, a si bien décrit les ministres corrompus, la vénalité et la débauche des cours des Princes, toutes choses qu'on ne trouve pas dans les «free governments ${ }^{9}$. De plus, est-ce un hasard si on retrouve sous la plume de Toland cette expression fréquente chez Sidney : «s'il y a du charme dans les mots »? Dans sa préface aux Discourses (non traduite en français), Toland affirme «the worth of the assertors of liberty " et l'estime universelle portée à Sidney.

La même année 1698, Toland publie à Vevey les Memoirs of Edmund Ludlow; ennemi de tout gouvernement autoritaire, Ludlow désapprouva l'usurpation de Cromwell qui redoutait en lui le répuolicain intransigeant, et se serait autant opposé à lui qu'au roi - Toland passe sous silence le régicide - sans son extrême vigilance.

La Vie de Harrington doit particulièrement attirer notre attention, puisque Toland dit préférer le modèle d'Oceana à celui de Milton. Mais la vision que se fait Toland d'une république est-elle bien celle de Harrington? Et, de fait, Toland dans cette Vie prend ses distances à l'égard de la république "Oceana »; il précise en quel sens la république est selon lui la meilleure forme de gouvernement, comme on le verra. Ce texte est plein de précautions. Toland, dans la préface, commence par prévenir l'objection qui consisterait à dire qu'il est séditieux et pernicieux de vouloir introduire une forme républicaine de gouvernement dans les îles britanniques et de publier les cuuvres de Harrington « who was the greatest Commonwealthman in the world». Le mot « république » est alors pris dans un sens péjoratif, et dans cette perspective Toland écrit : "An infallible expedient [...] to exclude a Commonwealth, is for the king to be the man of his people, and, according to his present Majesty glorious example, to find out the secret of so happily uniting two seemingly incompatible things, principality and liberty. " En ce sens, «I don't recommend a Commonwealth, but write the history of a Commonwealthman, fairly divulging the principles and pretences of that party». " Oceana » est la forme la plus parfaite de gouvernement populaire. Cela explique que ceux qui lui ont été le plus hostiles sont ceux qui ont rangé la tyrannie de Cromwell sous le nom spécieux de

8. A Collection of Several Pieces of Mr John Toland, now First Publish'd from his Original Manuscripts, with some Memoirs of his Life and Writings (cité par la suite comme Coll.), Londres, 1726 (posthume), t. II, p. 338. C'est moi qui souligne.

9. The Art of Governing by Partys [...] (cité par la suite comme Art), Londres, 1701, p. 112. Il est intéressant de noter qu'un long passage de cette section sur les dangers que court la liberté dans les monarchies absolues est cité par Thomas Gordon dans les Cato's Letters, 22 avril 1721 , t. I, p. 168-173. 
république. Harrington, quant à lui, a été fidèle à Charles $\mathrm{I}^{\mathrm{er}}$ et s'est opposé à l'« usurpateur ». Et Toland prend alors à son compte la critique du prétendu « Commonwealth», de Cromwell et de son protectorat.

Il ne faut pas conclure qu'aux yeux de Toland Harrington était partisan d'une démocratie; lors de son procès, il cita Aristote : un homme n'est libre que dans une démocratie; mais il ne reprend pas cette idée à son compte. Ses modèles sont divers : Israël, Sparte, Athènes, Carthage, Venise; et il admet des distinctions et des degrés; il y a, par exemple, dans une démocratie une "nobility et une "gentry». Mais Toland n'est pas favorable à un gouvernement mixte.

En 1699, paraissent à Londres les Memoirs of Denzil; Toland est l'éditeur, l'auteur de la dédicace et de l'introduction; Denzil, lord Hollis of Ifield, siégea au Long Parlement, mais fut l'objet d'une procédure d'« impeachment»; partisan des presbytériens contre les indépendants, il projeta l'«impeachment» de Cromwell. Toland qui rappelle dans son introduction sa fidélité au roi écrit ceci dans ces Mémoires insolemment dédiés à Cromwell : «it is an apology for that party which took arms not to destroy the king, or alter the constitution, but to restore the last and oblige the former to rule according to the law. »

À travers ces biographies et ces éditions, et dans tous ses ouvrages politiques, se dessine l'idée que se fait Toland d'un républicain; ce n'est certes pas sans prudence et parfois sans jouer sur les mots que Toland s'attribue à lui-même cette étiquette, au point que F. H. Heinemann, jouant sur le prénom originel de Toland, l'appelle «the Political Janus» dans «John Toland and the Age of Enlightenment». Mais dans tous les textes de Toland s'affirme une même idée : un républicain n'est pas ce que vous croyez; de 1699, dans la Préface d'Oceana, à 1717, dans The StateAnatomy of Great Britain ${ }^{10}$, Toland le répète : il n'y a pas un seul républicain au sens où vous l'entendez, «that is, men who are either for or against an aristocracy or a democracy, or if you'll have it worded otherwise, for the sovereignty of a Parliament and Privy Council, exclusive of all regal government ${ }^{11}$.

Bien plus, disait la " Dédicace » d'Oceana : «If a commonwealth be a government of laws enacted for the common good of all the people, not without their own consent or approbation; and that they are not wholly excluded, as in absolute monarchy [...] then it is undeniably manifest that the English government is already a Commonwealth, the most free and best

10. The State-Anatomy of Great Britain (cité par la suite comme S.A.), Londres, 1717, p. 10.

11. S.A., p. 9. 
constituted in all the world »; Jacques $\mathrm{I}^{\text {er }}$ ne s'est-il pas appelé lui-même " the greatest servant of the Commonwealth»?

Mais il y a en même temps dans cette préface une autre idée de la république, pour laquelle l'époque de Cromwell n'était pas mûre. Cette idée est très vaguement définie par le désir de liberté; peu d'hommes à ce moment-là désiraient une telle république; et si, après la tyrannie de Cromwell, le peuple n'a pas essayé de rétablir la république, je répondrai ceci, dit Toland: "the character which Tacitus gave the Romans of his time, may as well agree to the people of England, and it is that "they are able to bear neither absolute liberty nor absolute slavery". " Cette idée de la république hante peut-être secrètement Toland, mais ce n'est pas celle dont il se recommande, même s'il lui arrive de dire que la pire forme de république, la démocratie, vaut mieux que la tyrannie. Que veut dire Toland lorsqu'il se reconnaît être un républicain, qu'il revendique ce titre, qu'il est pour le principe de liberté : «I am [...] evidently and avowedly a Commonwealthsman ${ }^{12}$ ?

En premier lieu, il dénonce toutes les formes de tyrannie (y compris la tyrannie spirituelle de la «protestant popery» et il affirme fortement comme légitime la résistance au tyran : « it is lawful to resist and punish tyrants of all kinds, be it a single person, or greater number of men. " La parenté avec Locke est évidente; comme pour Locke et Sidney, les tyrans sont des bêtes féroces, des bêtes de proie. «They are to be treated after no other manner than wolves or tygers, which will be sure to destroy us if we are not beforehand with them "; " a despotick government is truly and properly a government of beasts $\gg$ ".

Un exemple de tyran et d'usurpateur qui revient très souvent chez Toland comme chez Sidney, c'est Cromwell. Dans sa Vie de Harrington, Toland désigne le prétendu Commonwealth qui suivit la mort de Charles $I^{\text {er }}$ comme «the rankest tyranny of Oliver Cromwell». Puis il écrit ceci : «Cromwell dyed a monstrous betrayer of those liberties with which he was intrusted by his country. » Dans Vindicius Liberius, il déplore que certains entendent par «commonwealth » l'époque des guerres civiles et l'usurpation tyrannique de Cromwell. Dans The Art of Restoring, il reconnaît à l'« usurpateur Cromwell ${ }^{14}$ le mérite d'avoir eu à cœur la religion protes-

12. L.H. VIII; Vindicius Liberius : or Mr Toland's Defence of Himself [...] wherein [...] Certain Passages of a Book Intitul'd "Christianity not Mysterious " Are Explain'd (cité par la suite comme V.L.), Londres, 1702, p. 128-127.

13. The Danger of Mercenary Parliaments (cité par la suite comme D.M.P.), 1699, reprod. in William Cobbett's Parliamentary History of England, Londres, 1809, vol. V, app. XI, p. CXV; Anglia Libera or the Limitation and Succession of the Crown of England, signé Janus Julius (cité par la suite comme A.L.), Londres, 1701, p. 178; The Memorial of the State of England, in Vindication of the Queen, the Church [...] (cité par la suite comme M.S.E.), Londres, 1705, p. 78.

14. V.L., p. 146. 
tante et d'avoir obtenu la liberté de conscience pour les Vaudois et l'impunité pour les protestants de Nîmes ${ }^{15}$.

Plus généralement, Toland combat les principes d'obéissance passive et de non-résistance à l'égard des pouvoirs arbitraires. Les serviles flatteurs des deux derniers rois (Charles II et Jacques II) ont « taught the people the ridiculous doctrine of passive obedience, as they allowed the prince an unlimited and despotic power ». Le clergé fait retentir les chaires de sa «slavish doctrine of passive obedience and non-resistance ». Partout on retrouve cette condamnation des chaires, ce qui n'est pas sans nous rappeler la Préface aux Deux Traités du gouvernement de Locke. Les chaires sont "cursed instruments of tyranny " ${ }^{16}$. L'obéissance passive, ou l'obéissance forcée, est comme une promesse que je fais à un voleur armé. C'est une astuce sinistre et nouvelle «to persuade the people by the most awful impressions of religion, and render no lesse a penalty than eternal damnation, to a non-resistance and passive obedience to the princes command of what nature soever ». Le clergé ne se contente pas de prêcher l'obéissance passive; il approuve les actions illégales des rois. Mais ce n'est pas sans retournement. Quand la Haute Église a vu que le roi Jacques II ramenait le papisme, elle s'est jointe à la Basse Église et aux dissidents pour se rebeller contre ce principe. En un mot, ces idées d'obéissance passive et de nonrésistance sont des "whimsical notions " ${ }^{17}$.

Plus dangereuse encore est l'idée d'un droit divin des rois, qui s'est manifestée avec une force jamais égalée au moment du tapage fait autour du projet d'Exclusion de Jacques $\Pi$. Toland dénonce cette idée tout au long de son ouvre. Ce droit divin concerne autant l'épiscopat que le roi. Les ennemis de sa présente Majesté (Guillaume III) en ont été partisans. Il y a eu connivence entre le clergé et les rois Stuart pour instiller cette insidieuse doctrine : "The divine right claim'd of late by some Christian kings, and the unreserved and passive obedience pretended by their flattering clergy to be due to them, if not a better expedient to support tyranny than that of the heathens, yet they were unquestionably intended for the same end and principle. " Ou encore : "The doctrine of indefeasible right was set up at first by a few aspiring clergymen, to ingratiate themselves with great princes, who had designs inconsistent with the law ${ }^{18}$.

15. The Art of Restoring, or the Piety and Probity of General Monk (cité par la suite comme A.R.), Londres, 1713 , p. 44.

16. Am., p. $163 ;$ D.M.P., p. CX; An Appeal to the Honest People against Wicked Priests [...] (cite par la suite comme Ap.), Londres, 1713, p. 31-32; The Jacobitism, Perjury and Popery of the High-Church Priests, Londres, 1710, p. 15; Ap., p. 33; S.A., p. 36.

17. A.L., p. $180-181 ; A r t$, p. $36 ;$ M.S.E., p. $18 ;$ S.A., p. 78.

18. Art, p. 15; V.L., p. 141; Letters to Serena, Londres, 1704 (repr. F. Frommann Verlag, 1964), trad. par D'HolBaCH, Lettres philosophiques sur l'origine des Préjugés [...] (cité par la suite comme $L . S$.), Londres, 1768 , lettre III, p. $100 ;$ S.A., p. 11. 
La cible principale, comme pour Locke et Sidney, c'est Filmer. La publication posthume de Patriarcha (1680) a été l'occasion de sermons et d'ouvrages passionnés : «There wanted not such as maintain'd the natural and divine right of arbitrary power itself, as well as of kingship, witness the publication of Filmer's Patriarcha »; «So unnatural scheme as theirs has given birth to a world of chimeras and inconstancies: such as the divine right of monarchical government, the patriarchal descent of the monarch himself». Ou encore : "With all their syllogisms they cou'd persuade [...] that their "Jure divino monarch" was any more sole landlord or proprietor, or Adam's irresistible heir, than he was the natural father of all his subjects. " Que l'on ne se méprenne pas : tout gouvernement est d'institution divine; tout pouvoir vient de Dieu (Rm. 13, 1), mais «let them not likewise play the Jesuits about the phrase of divine right, since none in these nations of any sort or sect denies the divine right of government as well as of every other institution for the good of mankind ». En un mot, ce droit divin est chimérique ${ }^{19}$.

Être républicain, c'est donc d'abord refuser toutes ces notions séditieuses. Mais comme nous l'avons entrevu, Toland propose une définition de l'idéal «républicain» qui comporte trois composantes essentielles: l'idée de consentement, celle de liberté et celle de monarchie mixte.

Un gouvernement, quelle que soit sa forme, doit avoir été l'effet d'un consentement. Le pouvoir lui est conféré par la société : «The power of governors is originally conferr'd by the society, and limited to their safety, wealth and glory, which makes the governors accountable for their trust. » Toland emploie les deux idées de contrat et de consentement, sans marquer, comme Locke, une nette préférence pour l'idée de consentement. Dans Anglia Libera, Toland parle de «the natural relation or original compact between all kings and their subjects». Dans High Church Display'd, texte qui est sans doute de Toland, il est question du contrat originel entre le roi et le peuple, "James II having endeavour'd to subvert the constitution of the kingdom by breaking the original contract between king and people». Il y a «consent and compact between the prince and the people; denying the original contract of government is to contradict and condemn the tenour of all our laws, and of every act of supreme legislative power, the force and efficacy of which subsists on the consent of the Crown, Lords and Commons». Hooker est, comme il se doit, l'autorité invoquée. Dans The State Anatomie, parlant des rois d'Angleterre, Toland parle de leur pompe, de leurs fonctions : ils agissent pour le bien commun de tout le peuple, «by their own consent and approbation, as they are

19. Art, p. $39 ;$ S.A., p. $15 ;$ Ap., p. $52 ;$ S.A., p. 4. 
represented in Parliament $\gg$. Les idées de contrat et de consentement sont indissolublement liées à celle de liberté ${ }^{20}$.

La liberté, comme l'avait fortement dit Locke dans son Second Traité du gouvernement, n'est pas la licence, mais elle est intimement associée à la loi. «By liberty, I do not mean licentiousness. " Ainsi, dans le véritable hymne à l'Angleterre qu'on trouve dans The Description of Epsom, on peut lire ceci : «Brave without blood, asserting liberty without falling into licentiousness, and making the laws a superior as well as a common rule to prince and people. » Toland affirme ses principes : liberté civile, tolérance religieuse et fídélité à la succession protestante. La liberté est définie ainsi : «a government of laws and not of wills, particularly our excellent constitution of King, Lords, Commons [...] the laws being to [the prince and the subjects] an equal rule." "Nothing, écrit Toland, is more consistent than law and liberty; nay, there cannot be any political liberty without law »; à l'appui : Cicéron, Oratio pro Aulo Cluentio (chap. 53). La même idée se trouve dans l'introduction de Toland aux Letters from the Right Honourable Shaftesbury ${ }^{21}$.

Plus fondamentalement encore, l'idée de loi évoque pour les républicains, ou plus largement pour les libéraux de cette époque, l'idée de constitution, ou même d'Ancienne Constitution. Comme l'écrit J. G. A. Pocock, les néo-harringtoniens ${ }^{22}$, au rang desquels il range Toland, identifiaient leur « commonwealth » avec l'Ancienne Constitution. À chaque instant, Toland rappelle l'excellence de la constitution anglaise - mais aussi les menaces auxquelles elle est exposée. Cette constitution repose sur des lois fondamentales ${ }^{23}$. Et par exemple «the present limitations to the succession of the crown are historically prov'd to be the nature of our constitution ». Qu'on

20. V.L., p. 126; A.L., p. 23; High-Church Display'd: Being a Compleat History of the Affair of Dr Sacheverell (cité par la suite comme H.C.), Londres, 1711, p. 182, 185, 186;S.A., p. 12. "Those eternal notions of liberty and slavery, I imbibed with the first milk I sucked from the Muses » ("To the Right Honourable the Lord Southwell », 27 avril 1720, in Coll., t. II, p. 459).

21. Mangoneutes in Tetradymus, Containing Hodegus, Clidophorus, Hypatia, Mangoneutes, Being a Defence of Nazarenus (cité par la suite comme M.), Londres, 1720, p. 233; The Description of Epsom [...] (cité par la suite comme D.E.), Londres, 1711, p. 19; Another Memorial for the Most Honourable Earl of*** (cité par la suite comme An.M.), Londres, 17 décembre 1711, in Coll., t. II, p. 221; S.A., p. 12; Introduction à Letters from the Right Honourable the Late Earl of Shaftesbury to Robert Molesworth (cité par la suite comme L.Sh.), Londres, 1721, p. VII.

22. Voir John Greville Agard Pocock, Politics, Language and Time, New York, 1973, p. 133 : « Macchiavelli, Harrington [...]». Je rappelle que pour Pocock la différence entre Harrington et les néo-harringtoniens c'est que le premier ne se réfêre pas à l'«ancienne constitution »; « l'essence du néo-harringtonisme est dans la réconciliation de la vision que se fait Harrington d'une république équilibrée de propriétaires avec la vision anglaise plus ancienne d'une constitution antique » (ibid., p. 133).

23. A.L., p. 126. On sait que cette idée de loi fondamentale n'est pas admise par tous en Angleterre; Filmer et Hobbes, par ex., la refusent (cf. des références dans mon article « La pensée politique de Sir Robert Filmer », in La Pensée politique anglaise de Hooker à Hume, 
ne dise pas que c'est là altérer notre «ancienne constitution »; faire de nouvelles lois, limitations ou précédents « will be the ancient constitution (if there be any charm in this expression) to our posterity, 6 or 7 ages hence $»$. Ce n'est donc pas sans quelque ironie que Toland utilise l'expression « ancienne constitution». Le bonheur des sujets est «suitable to the nature of our fundamental constitution». La religion nationale est «an essential part of our constitution ${ }^{24}$.

Pour Toland, comme pour Sidney et d'autres « républicains », la constitution mixte est la plus parfaite, la plus libre. Ce n'est pas l'opinion de Harrington. Mais Toland l'affirme maintes fois. Cela veut dire d'abord que le régime est monarchique : «Kingship [...] is essential to our constitution [...] a proportionable mixture of those three kinds, the monarchical, the aristocratical, the democratical »; et que les autorités, comme on pouvait s'y attendre sont Aristote, Cicéron, Polybe.

Dès 1700, Toland exposait donc sa préférence pour le gouvernement mixte. Dans un tel gouvernement, le « commonwealthsman finds he injoys liberty under the security of equal laws, and that the rest of the subjects are fully satisfied they live under a government which is a monarchy in effect as well as in name. There's not a man alive that excedes my affection to a mixt form of government, by the antients counted the most perfect »; aux autorités déjà citées s'ajoutent Tite-Live, Thomas More et Machiavel ${ }^{25}$.

En 1701, Toland, non sans quelque paradoxe, identifie gouvernement mixte et république :

"When 'tis [the administration] shared between the Commons, the Lords and the Supreme magistrate (term him King, Duke, Emperor, or what you please) 'tis a mixt form, and is by Polybius and many judicious politicians among the ancients esteem'd the most equal, lasting, and perfect of all others. In this sense England is undeniably a Commonwealth, tho' it be ordinarily stil'd a Monarchy because the chief Magistrat is called $a$ King. Such as are afraid therefore that England should becom a Commonwealth, may be suspected not to understand their own language; and those who talk of making it one, may dream of turning it into an aristocracy or democracy, but can never make it a Commonwealth more than it is already. This is our admirable Constitution. "

Dans une lettre du 26 juin 1705, à M. ***, Toland dit ceci : « concerning the several forms of free government (which are all good in their kinds,

Paris, Presses universitaires de France, 1994, p. 67, 203. Dans D.M.P., p. CX, Toland accuse Jacques II d'avoir opéré «a breach and violation of most of our fundamental laws ».

24. A.L. p. 105 ; S.A., p. $10 ;$ Art, p. 94 ; S.A., p. 20.

25. Paradoxes of State Relating to the Present Juncture of Affairs in England and the Rest of Europe (cité par la suite comme P.S.), Londres, 1702 , p. $5 ;$ S.A., p. $9 ; L . H$., p. VIII. À la différence de Harrington et de beaucoup d'autres, Toland ne donne pas le modèle de Venise comme le modèle le plus parfait de régime mixte. Il en parle seulement à propos de la noblesse. 
tho' not all equally so) I justly think our own mixt constitution to be the best that is now extant anywhere. » Toland se plaint de la Haute Église, qui est opposée à notre gouvernement mixte et au droit de Sa Majesté : «The High Church is not the Church of England ${ }^{26}$.

Bien sûr, le Parlement est le pivot de ce gouvernement mixte. Toland l'affirme avec plus de force que Locke (qui en parle à peine). Un des premiers textes politiques qui soient attribués, avec raison je crois, à Toland, porte le titre significatif : The Danger of Mercenary Parliaments. Le rôle du Parlement est de soutenir la juste prérogative du roi et de protéger les droits et les privilèges justes des sujets. Après avoir défini ses tâches, Toland insiste sur ces points essentiels : le Parlement est « $a$ poise and balance between the two extreme contending powers of absolute monarchy and anarchy, $[\ldots]$ a check and curb to insolent and licentious ministers, and a terror to ambitious and overgrown statesmen; [...] giving their advice to his majesty in all matters of importance, [...] making necessary laws to preserve or improve our constitution ». Il était urgent de dénoncer les dangers qui le menacent, brigues et corruptions. En 1697, An Apology for $M$. Toland commence de façon caractéristique par montrer l'importance des Parlements, même s'ils se trompent quelquefois, cet inconvénient étant « infinitely overbalanc'd by several excellent laws». Les Parlements, « reserve a power to themselves of restraining the exorbitancy of princes and deposing tyrants". "Henry VIII was only a trustee appointed by the Parliament ${ }^{27}$.

Reprenant, dans The Art of Governing by Partys, les idées de The Danger of Mercenary Parliaments, texte auquel il se réfère d'ailleurs, Toland dénonce le danger d'«officers » à la solde de l'exécutif. La solution serait un Parlement annuel; l'Act «for triennal Parliaments» (1694) est un bon pas en ce sens. "There is no other public credit in England but that of the Parliament. But if a Parliament shou'd once break their contract with us, to whom shall we fly for a remedy ${ }^{28}$ ?

Le Parlement vient au secours de la Constitution: "The Constitution was rescu'd from the invasions made upon it by the late King James; and still capable by the frequency of Parliament to have the remaining defects occasionally amended or supplied, which is an advantage peculiar only to

26. Art, p. 26; Coll., t. II, p. 338 ; M.S.E., p. 13. Dans V.L., p. 14, on trouve cette formule : "We mean by this word [Commonwealth] the antient and present constitution of England under King, Lords, and Commons. " Dans Hodegus in Tetradymus, op. cit. supra n. 21, p. 6, Toland dit, parlant du * Commonwealth of Moses ", qu'il est " of all forms I think the most excellent and perfect " et il annonce un écrit sur la République de Moïse.

27. A.L., p. 117, 123.

28. Art, p. 68 sqq., 125. 
free government. » Et dans The Grand Mystery Laid Open, Toland emploie l'expression «The sacredness of Parliamentary securities » 29.

Il se dégage de tous ces textes l'idée que le gouvernement mixte est un gouvernement équilibré dont les parties à la fois collaborent et se répriment entre elles. Toland reprend, mais en la détournant de son sens, l'idée, chère à Harrington, d'équilibre, de «balance ». Ainsi, dans The State Anatomie, après avoir montré que le Parlement n'est pas un pouvoir judiciaire (ce qui est discutable à cette époque), mais le pouvoir législatif suprême, il dit des trois États (roi, Chambre des lords, Chambre des communes) : «as they are mutual awes and checks on one another, so they are to one another mutual lights and assistants. In the equilibrium of their body [...] consists our greatest happiness $\gg{ }^{30}$.

J. G. A. Pocock résume bien cette situation : «by preserving their independance against the Court, Parliament and its extension the Country were preserving what was called "the balance of the constitution" $" 31$.

Cette idée d'équilibre, de «balance » nous la retrouverons à un autre niveau. Dès la Vie de Harrington, Toland pensait que la doctrine de la «balance» conçue par l'auteur d'Oceana pouvait éclairer un bon monarque. Il reprend d'ailleurs parfois à son compte le concept de «balance » selon Harrington. Ainsi après avoir montré que la liberté s'était prodigieusement accrue récemment, il écrit qu'à la fin « the overbalance of property (and consequently of power) fell into the scale of the Commons, where it seems to be now wholly fixt, and according to which the government is in a manner new modell'd ». Mais l'idée qui lui est propre, et qui sera reprise avec l'ampleur que l'on sait par Montesquieu, c'est qu'en Angleterre, régie par un gouvernement libre, le roi, les lords et les communes, qui ont le pouvoir législatif, « are a mutual check and balance on one another's oversights or encroachments ». Il faut qu'il y ait un vrai équilibre, et que tout le poids ne soit pas sur un seul plateau, comme ce serait le cas si les députés ne votaient pas librement, mais se laissaient acheter par l'espoir de gagner des places ou la crainte de les perdre. Ne détruisons pas « that excellent balance of power which is secured by it (the consent of the Crown, the Lords and Commons) " 32 .

29. A.R., p. 13; The Grand Mystery Laid Open [...] to Weaken the Hanover Succession [...] (cité par la suite comme G.M.), Londres, 1714, p. 29.

30. S.A., p. 39.

31. Voir J. G. A. Pocock, op. cit. supra n. 22, p. 128.

32. A.L., p. 19;Art, p. 31;D.M.P., p. CIX;H.C., p. 32. On trouve un texte à peu près semblable dans Dunkirk or Dover; or The Queen's Honour, the Nation's Safety, the Liberties of Europe and the Peace of the Lord [...], Londres, 1713, p. 9: «In a free government [...] the people having rights and priviledges of their own, are thoroughly verst in the prerogatives and immunities of the coordinate legislative states, which ever must be a check on each other, and between whom there must be kept an exact balance and proportion. $\$$ A. SIDNEY, in op. cit. supra n. 3, chap. III, p. 43, 364 de la trad. fr., insiste aussi sur l'équilibre de ce gouvernement 
Cet équilibre suppose la séparation des pouvoirs :

"In the best governments, the legislative and executive powers are always plac'd in different hands: for otherwise the makers of the laws might exempt themselves from their juridiction, or suit them to their own advantage; whereas becoming like other men subject to them as soon as they are ratified, and the sentence of the breach to be pronounc'd by other persons, they'll take care, at least for their own sakes, that they be calculated for the common good."

Étranger à ce bel équilibre : le premier ministre; Toland dénonce ceux qui parlent de «New and Old Ministry », des favoris qui espèrent que leur parti les portera à ce poste : "We are ignorant still who these managers and State-mountebanks are; for our government knows no such thing as a Prime Minister : we read of no rank, no business, no salary establishment for such a person ${ }^{33}$.

Toutes ces idées, tous ces principes ne sont pas très originaux; les divers penseurs dits « républicains » les ont défendus de façon différente. Mais Toland n'est pas un théoricien abstrait; il a été étroitement mêlé à l'actualité politique particulièrement animée qui a accompagné toute son existence. De grands événements se produisirent: l'avènement des partis, l'affaire de la succession royale, les progrès de la tolérance, la recherche d'un équilibre européen. Sur toutes ces questions, Toland se comporte en whig, ou, si l'on préfère, en partisan du " country party », et c'est toujours sous l'égide de la liberté qu'il recherche des solutions. Cependant, l'attitude de Toland à l'égard des partis en général n'a pas été sans fluctuations; J. A. W. Gunn décrit rapidement cette évolution ${ }^{34}$. Quelques textes sont révélateurs. Ainsi, dans The Militia Reform'd, Toland déplore les «factions » qui nous divisent, et bien plus les divisions à l'intérieur des factions elles-mêmes :

"One says, the Tories will never heartily consent to any model that makes the Militia useful : another replies that this is only an ill-natur'd insinuation, while some of the Whigs oppose the thing openly, and are glad of any pretence to

mixte; les nations raisonnables ont trouvé comme remède de « diviser et équilibrer les pouvoirs de leur gouvernement de telle façon qu'un seul homme ou un petit nombre d'hommes ne soient pas en état d'opprimer et de détruire ceux qu'ils doivent préserver et protéger ".

33. Art, p. $80 ;$ A.L., p. 165 . Quelques années plus tard, Mandeville présentera dans la deuxième partie de la Fable des abeilles un portrait très chargé du premier ministre. Selon Mandeville, le premier ministre n'est pas prévu par la constitution. Hume considère au contraire que son existence est un trait essentiel des monarchies limitées, et il en fait remonter l'existence au règne d'Édouard II (The History of Great Britain, anno 1315).

34. Voir John Alexander Wilson Gunv, Factions no more. Attitudes to Party in Government and Opposition in Eighteenth-Century England, Londres, 1972, p. 252, n. 7. 
conceal their true reasons. But these names are now of a very doubtful signification. We hear of Court and Country, of apostate and adhering Whigs; nor are the Tories more united among themselves. "

Il ajoute plus loin : "Certainly a true patriot can be of no faction." Amyntor, l'année suivante, est aussi sévère; Toland vient d'évoquer les sermons annuels célébrant la mort de Charles $\mathrm{I}^{\mathrm{er}}$ : «It was likewise observed how much these sermons contributed to raise animosities and feuds in the Kingdom, and to continue the fatal distinctions of names and parties, which every good man should desire might be abolished or bury'd in eternal oblivion $"$ s.

L'ouvrage le plus important sur ce problème - mais aussi le plus ambigu - est The Art of Governing by Partys; le sous-titre indique les domaines où Toland va analyser les effets déplorables de la division en partis : "in religion, in politics, in Parliament, on the Bench and in the Ministry, with the ill effects of Partys on the People in general, the King in particular, and all our foren Affairs, as well as on our Credit and Trade, in Peace or War. » La critique des partis s'exprime dans ce livre avec une grande violence. En voici quelques exemples : «Of all the plagues - since the death of Elizabeth none has spread the contagion wider [...] than the implacable animosity of contending parties. » Ces partis se désignent les uns les autres « with opprobrious names. In Parliament they were call'd Patriots and Loyalists, or the Court and Country Parties; but in all other places they were distinguisht into Whigs and Tories, being the names of Highwaymen in Scotland and Ireland». Toland parle plus loin des « contumelious nicknames of Whig and Tory ". Même quand un prince ne gouverne pas par des partis ou ne se laisse pas gouverner par eux, " yet it is out of his power [...] not to be frequently deceived, abus'd and endanger'd by their tricks and selfish ends ».

Il faut mettre en évidence les sources et les ressorts de ces partis. Jusqu'à l'accession des Stuarts, «we never knew the art of governing by parties »; cet art s'est retourné contre Charles $\mathrm{I}^{\mathrm{er}}$; mais « this execrable policy was brought to perfection under Charles II »; " this is the true spring of all those pernicious divisions [...], parties [...], clubs and cabals»; il a créé les partis pour notre destruction. Toland loue Guillaume III de ne pas poursuivre cette politique: "'Tis manifest by all his steps that he loves not to govern by parties. » Mais un ressort plus important encore, ce sont les ministres : «the great spring [...] of all party-making and factions: the ministers of State [...], their profound skill in the Arcana Imperii »; ils se prétendent «absolute masters of what they call "Reasons of State" 》.

35. The Militia Reform'd [...] (cité par la suite comme M.R.), Londres, 1698, p. 6, 9; Am., p. 163. 
Or il faut éviter ces divisions dangereuses : «Divisions ought carefully to be avoided in all good governments, and a King can never lessen himself more than by healing of a party; for thereby he becoms only the King of a faction, and ceases to be the common father of his people. "Toland décrit la pratique politique désastreuse de ces décennies; à chaque occasion, un parti s'oppose systématiquement à un autre; dès qu'une proposition de loi « was brought to the house by one party, [it] was for that only reason fiercely oppos'd by the other [...] so that the best laws were got or lost according as they happen'd to be mov'd or oppos'd by the stronger side ». Certes, les marchés entre partis ont conduit à voter de bonnes lois; " but how many excellent laws pass with much difficulty or are quite laid aside, purely for being mov'd by one of the parties? ». De plus, les élections ne se déroulent pas de façon rationnelle; comme Hobbes, Locke et bien d'autres, Toland dénonce les «bourgs pourris », donnant les exemples traditionnels, Winchelsea, Old Sarum. La division des partis entraîne la division des gens, corrompt la morale, dissout le gouvernement. Les magistrats et l'administration sont dangereusement affectés par cette division en partis, «as, with us in England, the King is always under very ill circumstances [...], but principally when those factions are of his own creation ». Enfin, cette division affaiblit la nation : si nous continuons nos divisions intérieures, nous ne pourrons exercer notre pouvoir à l'extérieur ${ }^{36}$.

Quant à ceux qui voudraient l'union, "branded with the name of Trimmers $^{37}$, and with respect of their opinions in religion, they are call'd Latitudinarians [and] are hated by all the rest $»$. On redoute leur modération, le calme de leurs admonestations. Faut-il choisir la neutralité? C'est une solution que Toland refuse à la fin de The Art of Governing :

« Did I follow my natural inclination I shou'd be always for a neutrality, and I promise to be a very indifferent judge when the critical oportunity presents itself; but when there's a sedition in the city, I think (with Solon) it ought to be capital for a man to remain an unconcern'd spectator, but that he shou'd be necessitated to ingage on the side he most approv $d{ }^{38}$.

Quelques années plus tard, en 1714 ou 1715, dans A Memorial Presented to a Minister of State, Toland exprime à l'égard des "Trimmers" une sévérité sans nuance : "The Trimmers are timorous pusillanimous knaves who [...] would not provoke any party, but smile upon all, and ever leaning towards the prevailing side, or hovering between both till they see who gets

36. Art, p. 7, 35, 119, 108, 8, 49, 92-93, 41, 58, 64, 116, 134, 142.

37. Terme nautique désignant ce qui équilibre le navire; il fut attribué dans un sens péjoratif à propos de George Savile, lord Halifax (1633-1695).

38. Art, p. 178. 
the better ». Dans The State-Anatomy of Great Britain enfin, il refuse la position des neutres, qui sont en réalité des opportunistes : «Trimmer like a bird of prey hovering over two armies, being ready to feed of either side. »

Dès la fin de The Art of Governing, Toland affirme sa préférence : «I believe there's nobody who does not imagin one of 'em to be more in the right than the other: and I have not disguis'd in this whole discourse, which of 'em has Most reason in my opinion ${ }^{39}$.

Il est bien clair en effet que sa préférence va aux whigs, même s'il écrit en tête du chapitre IX : "The only remedy against all the michief [sic] of Partys is a Parliament equally constituted. » Les meilleurs des whigs, dit par exemple Toland, sont des membres de l'Église d'Angleterre; ils adhèrent à leurs principes malgré la prison ou l'exil; les neuf dixièmes sont pour la liberté. Et surtout, «there can be no balancing in prefering a Whig to a Tory, that is, a free government to arbitrary power, the protestant religion to popery, England to France, and if I may add one thing more, King William to King James ». À l'inverse, Toland accable les tories d'insultes; après l'arrivée du prince d'Orange, "alas, the Tories return'd to their vomit »; ils ne voient en celui-ci qu' un régent, "accountable to his father in law », un simple roi «de facto»; ils ont trahi le roi, comme sous Charles II ils avaient trahi la nation. Les ministres tories espèrent s'enrichir en s'alliant avec la France; " they are throly verst in this mystery of iniquity »; que le roi se méfie d'un ministre tory ${ }^{40}$.

L'attitude de Toland à l'égard des partis est encore assez ambiguë dans Paradoxes of State : "Whatever names may have been formerly coin'd to distinguish parties here in England, there is at present neither Whig nor Tory, Williamite or Jacobite, nor any real distinction but between those that are in a French, and those that are in an English interest. »On trouve la même défiance dans The Memorial of the State of England: que les ministres ne deviennent pas chefs de factions, sinon « they will probably in a little time be undermined and blown up by the contrary party, thou' it shou'd be the worst and weakest of the two ".

En 1711, dans A Memorial for the most Honourable the Earl of***, Moland souhaite une coalition «between the true friends of their country, which are the moderate Whigs, and the Moderate Tories $\gg{ }^{41}$.

C'est seulement en 1717, dans The State-Anatomy of Great Britain, que Toland accepte, non sans quelque réserve, l'existence des partis. Il

39. A Memorial Presented to a Minister of State (cité par la suite comme Mem.M.), 1714 ou 1715, Coll., t. II, p. 245; S.A., p. 103; Art, p. 177.

40. Art, p. 164, 39, 50, 54, 44, 46, 94, 109.

41. P.S., p. 3; M.S.E., p. 4; c'est sans doute à ce texte que fait allusion J. A.W. GunN, op. cit. supra n. 34, mais il indique par erreur p. $44:$ A Memorial for the Most Honourable Earl of***, s.d. (sans doute 1711), Coll., t. II, p. 217. 
commence, dans la préface, par déplorer la division en partis, qu'il assimile à l'existence des hérésies dans l'Église, mais, ajoute-t-il, « held within due bounds, they always keep it [the State] from stagnation [...] provided they all agree to love King George ». Les partis sont source d'émulation.

Quoi qu'il en soit de l'attitude théorique de Toland à l'égard de l'existence de partis, sa sympathie pour les whigs est évidente depuis les premiers écrits politiques importants. Nous avons rencontré The Art of Governing, de 1701. Anglia Libera, juste postérieur (1701), tout en défendant des thèses proches de celles des whigs, ne raisonne pas en termes de parti. Dans Vindicius Liberius, après avoir défini la république et s'être déclaré républicain, Toland dit ceci : «I take England to be now a Commonwealth. This is what I mean by being a Whig. " Et l'on va, ce qui n'est pas surprenant, retrouver dans les idéaux whigs les principes qui animaient Toland républicain. Quelques textes sont caractéristiques. Ainsi dans The Memorial of the State of England:

"The Whigs maintain that all governments are (under God) originally from the choice of the people for whom and by whom they are establish'd; and that no government is good that does not consist of laws, by which the magistrates are restrain'd and regulated no less than the subjects for their common happiness [...]. They like none [no form of government] so well as our own mix'd form of King, Lords, Commons, the latter being purely elective, the second absolutely hereditary $\gg{ }^{42}$.

De ces principes, on peut conclure qu'il est légitime de résister par les armes aux tyrans et aux usurpateurs.

En 1710, dans les Reflections on $D^{r}$ Sacheverells Sermon ${ }^{43}$, il définit les whigs comme des « zealous sticklers for civil liberty and sworn enemies to ecclesiastical tyranny»; et de même qu'il avait proclamé dans Vindicius Liberius, comme on l'a vu : «I am [...] avowedly a Commonwealthsman », il dit ici : «For my own part [...] I shall be a good Whig in England. » Et l'année suivante, dans Another Memorial, Toland manifeste à la fois ses convictions politiques et sa réserve à l'égard des partis :

«For my own part, as I have ever been so I still declare myself to be a Whig: a Whig, I say, by denomination as well as by principle, in the sense I have

42. V.L., p. $133 ;$ M.S.E., p. 76.

43. Il s'agit du violent sermon prêché à Saint-Paul le 5 novembre 1708 par le prêtre High Church Henry Sacheverell, et qui parut sous le titre «The Perils of False Brethren, both in Church and State ", contre la tolérance, les dissidents, les whigs, la Révolution. Le gouvernement procéda à la mise en accusation de Sacheverell, ce qui suscita des pamphlets et des émeutes. Sacheverell, malgré la sympathie de la reine Anne, fut condamné à ne pas prêcher pendant trois ans. Voir Reflections on D' Sacheverells Sermon (cité par la suite comme R.S.), Londres, 1710, p. 2, 13. 
explain'd this word in a book I wrote by your Lordship's allowance and encouragement, The Memorial of the State of England. But I declare at the same time that I am far from thinking the Prince, or even his chief Minister, should make himself the head of a party; which will not only render either of both contemptible, but likewise plunge 'em into inextricable difficulties. »

La division entre whigs et tories est dès lors clairement revendiquée : «The division of Whigs and Tories is so far from being always hurtful, that it is sometimes necessary, and not seldom creates an emulation who shall best deserve the publick. " On voit clairement par contraste ce qu'est un tory aux yeux de Toland; les qualificatifs sont souvent violents, comme nous avons pu le voir. Ainsi dans The Description of Epsom, après avoir exprimé son mépris pour les «degenerate Whigs», il écrit: «Let those Tories be for ever abhorr'd, who, like hungry dogs, return to their vomit again, by madly offering both laws and liberty to the arbitrary will of any mortal, tho the best of Kings or Queens. " En 1714 ou 1715, dans A Memorial Presented to a Minister of State, Toland distingue deux sortes de tories : les premiers, «Non-jurors, perfect Rosicrucians in government, a stupid, illiterate, stubborn, positive, noisy and impudent generation »; ils ne sont pas très dangereux tant qu'ils tiennent leur serment; mais on ne peut se fier à eux. Les seconds sont si dévoués à l'Église d'Angleterre qu'ils sont implacables pour les autres; mais ils ne sont pas si dangereux que les premiers; ils sont hostiles à un monarque papiste; il faut les traiter avec douceur ${ }^{44}$.

Ce même Memorial résume l'attitude et le programme des whigs. Ils sont :

«virtuous, wise and industrious Church of England men; yet brotherly indulgent towards other Protestants, and all for a general naturalization. To these ought to be added the sectaries who heartily join with them on one common bottom, against popery and slavery either in Church or State. The Whigs of all denominations (whatever may be their failings or differences in other respects) are immensely staunch for liberty civil and religious, for trade and the balance of Europe. So far are they from being against Kingship (as their enemies foolishly calumniate them) that they are to a man most zealous for the Act of Succession ${ }^{45}$, particularly faithful to King George ${ }^{46}$.

44. An.M., Coll., t. II, p. 228 ; G.M., p. 14; D.E., p. $20 ;$ Mem.M., Coll., t. II, p. 243.

45. Il s'agit de l'« Act of Settlement », en 1701. La reine Marie mourut en 1694, sans enfant. En prévision du cas où Guillaume III ne se remarierait pas et n'aurait pas d'enfant, et où la reine Anne qui lui succéda n'aurait pas d'enfant vivant, cet Acte prévoyait que la couronne reviendrait au parent le plus proche des Stuarts, Sophie, électrice de Hanovre. On sait que Toland a publié à Londres en 1705 An Account of the Courts of Prussia and Hanover (cité par la suite comme $A . C$.), en fait des récits de 1702 , traduit en français en 1706 , où il fait l'éloge de Sophie-Charlotte de Prusse et surtout de Sophie de Hanovre.

46. Mem.M., Coll., t. II, p. 244-245. 
Certains éléments de l'idéal « républicain » se retrouvent ici.

Il nous reste à mettre en lumière quelques problèmes importants qui ont tous comme condition de solution la recherche d'une plus grande liberté.

$\mathrm{Du}$ point de vue de la politique intérieure, c'est l'idée d'équilibre, de «balance », que nous avons rencontrée, qui doit inspirer les solutions. Et c'est une valeur commune aux penseurs whigs, aux républicains et aux partisans d'un régime mixte; mais c'est aussi une valeur que partagent les tories modérés, comme Bolingbroke.

Les idées de liberté et d'équilibre interviennent dans la solution de problèmes concrets. Ainsi pour le choix des rois ${ }^{47}$ qui doit se faire entre les deux extrêmes de l'élection et de l'hérédité absolue :

«Our manner of constituting the chief magistrate is the laudable mean between two most vitious extremes; for to elect the person anew on every King's death or demise, would expose us to all the uncertainty, confusions, civil wars, bribery, and other mischiefs so frequent and familiar in Poland: as on the other hand the succession absolutely hereditary would expose us without remedy to be govern'd by tyrants, madmen, fools or idiots ${ }^{48}$.

La solution est de limiter la succession sous certaines conditions à une famille, en se réservant d'exclure l'héritier le plus proche s'il est incapable ou si un membre de sa famille est plus capable, et même de transférer le droit de succession d'une famille à une autre. Toland, comme Sidney, aime à rappeler que les rois saxons étaient élus et que les rois tiennent leur pouvoir de la loi. Tous deux aiment citer Bracton et Fortescue : le roi est le ministre de Dieu sur terre et doit protéger les lois et les sujets. La prérogative « is but the Prince discretionary power to act for the public good, and not for his own good exclusive of it, where the law has not determined what he is to do ${ }^{49}$.

Selon Toland, comme selon Sidney, la noblesse joue un rôle central dans le schème politique. On sait que pour Harrington la monarchie doit être soutenue soit par l'armée soit par la noblesse ${ }^{50}$. Des textes célèbres, Letter from a Person of Quality (novembre 1675, sans doute de Locke) et le Discours du comte de Shaftesbury à la Chambre Haute le 20 octobre 1675

47. Incidemment, et comme il est de tradition, Toland appelle les rois « the God's Vice.

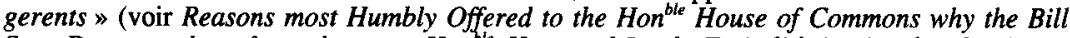
Sent Down to them from the most Hon ble House of Lords Entitul'd An Act for the Better Securing the Dependancy of the Kingdom of Ireland upon the Crown of Great Britain Shou'd not Pass into a Law (cité par la suite comme Reasons), Londres, 1720, p. 7.

48. A.L., p. 108.

49. H.C., p. 214 ; S.A., p. 5.

50. Oceana, op. cit. supra n. 1, p. 53, 70, 72. 
reprennent cette idée, en privilégiant comme il se doit la noblesse par rapport à l'armée. Dans Anglia Libera, Toland montre l'activité de la noblesse dans un gouvernement libre; la noblesse anglaise est zélée pour la liberté et la religion protestante; elle s'oppose aux mesures menaçantes de la France et soutient l'alliance avec la Hollande. Encore faut-il s'entendre sur ce qu'est la noblesse : «True Nobility dos not consist in titles, ornaments or attendance (tho I see no hurt in such distinctions) but in being the leaders of the people in warr as well as the protectors and guides in peace. " Dans les monarchies absolues, on fait grand bruit des titres imaginaires et inutiles; " but in free governments, the nobility make a substantial part of the constitution, and are the very soul of the State ». Dans The Art of Restoring, Toland constate que depuis l'époque de Charles Quint le pouvoir des nobles est entièrement aboli en France. Comme Sidney, Toland pense que l'on pourrait anoblir les plus valeureux, en particulier les grands marchands : "The Whigs are the trading people of this country [...]; we being a trading nation ought, among other incouragements to commerce, to aggregate, from time to time, some of the most eminent citizens into the body of our nobility ${ }^{51}$.

L'accent mis sur l'importance du Parlement est un trait spécifiquement whig ${ }^{52}$. Nous avons rencontré le texte consacré au « Danger of Mercenary Parliaments ", dont Toland reprend le thème dans The Art of Governing. Toland insiste pour que les Parlements soient fréquents. Le «Triennal Act » ne suffit pas. Sur ce point, whigs et tories s'opposent. Dans Letters from the Right Honourable the Late Earl of Shaftesbury, Toland, qui en est l'éditeur, rappelle l'opposition des tories aux Parlements fréquents et la position contraire de Shaftesbury (le moraliste); il cite "the old English axiom : we can never be hurt but by a Parliament ${ }^{53}$.

Ce qui importe surtout, c'est la liberté des débats; «freedom of debates [à la Chambre des communes] [...] is essential to their Constitution $\gg^{54}$.

La liberté est au cœur du programme whig. Il s'agit tout d'abord de la liberté de conscience, qui entraîne la tolérance. La liberté et l'égalité des hommes sont les vrais principes de la société civile : ainsi s'ouvre Anglia Libera; et plus loin : "where there is no liberty of conscience, there can be no civil liberty, no incouragement for industry, no proper means of rendring the country populous, no possibility of men's freely informing themselves concerning the true religion, nor any refuge or protection for the distresst, which is the greatest glory of free governments. " Dans An Account of the Courts of Prussia and Hanover, Toland rend hommage à la Prusse

51. A.L., p. 58; A.R., p. 5 ; S.A., p. 45.

52. On lira avec intérêt Reasons où Toland réclame l'indépendance du parlement d'Irlande.

53. L.Sh., Introd., p. XIII et XX.

54. Am., p. 168; même thème in A.R., p. 13. 
pour « the intire liberty of conscience which all good Christians enjoy in this place »; cela encourage les étrangers à s'établir parmi eux. À l'inverse, Sacheverell fait de la liberté de conscience une doctrine «treacherous and detestable ». Pourtant, la liberté de conscience n'est pas le laxisme; elle $\mathrm{n}$ 'est $\mathrm{ni}$ « licentiousness in morals, nor indifference as to all religions ». Et si, comme le dit Mangoneutes, la liberté de penser « which is the only good thing in this world 》 se confond avec « the protestant interest », c'est parce qu'en certains pays cette liberté ne peut s'exprimer ${ }^{55}$.

La liberté de conscience entraîne donc nécessairement la tolérance, comme il est indiqué dans The State-Anatomy. Être tolérant, c'est ne considérer que la conscience, la liberté, « the persuasion of men; the equity of this liberty is grounded upon the use of reason which is equally the right of all men ». Comme Milton, Sidney ou Locke, Toland exclut les catholiques de la tolérance, parce qu'ils sont eux-mêmes intolérants. Surtout, ils reconnaissent un prince étranger, un pape qui dispense de tenir ses serments, qui ne garde pas sa foi avec les hérétiques : le papisme est pire que l'athéisme; les Turcs et les païens au moins sont tolérants ${ }^{56}$. Mais il faut tolérer les dissidents; la diversité dans la même religion est compatible avec un bon gouvernement. Dans Paradoxes of State, Toland remarquait que la tolérance diminuait l'ardeur des dissidents, que les controverses étaient plus calmes, et qu'ils venaient quelquefois dans les églises publiques. La tolérance et la multiplicité des sectes peuvent coexister avec l'Église nationale. "'Tis not toleration (the source of science), but persecution (the root of ignorance) that produces sedition and trouble. " Et dans High Church Display'd, il dit de la tolérance envers les dissidents qu'elle est «one of the earliest and happiest results of the revolution itself ». Un texte qui sonne comme un ultime manifeste est ce passage de Mangoneutes :

«Civil liberty and religious toleration, as the most desirable thing in this world, the most conducing to peace, plenty, knowledge, and every kind of happiness, have been the two main objects of all my writings. But as by liberty I do not mean licentiousness, so by toleration I do no mean indifference, and much less an approbation of every religion that I could suffer. To be more particular, I solemnly protest to your Lordship that the religion taught by JesusChrist and his Apostles (but not as since corrupted by the substractions, additions, or other alterations of any particular man or company of men) is that I think I infinitely prefer before all others ${ }^{57}$.

55. A.L., p. 1, $100 ;$ A.C., p. $23 ;$ R.S., p. 7 ; S.A., p. $27 ;$ M., p. 55.

56. L.M., p. $36 ;$ S.A., p. 21.

57. P.S., p. $7 ;$ R.S., p. $4 ; H . C$., p. $216 ; M$., p. 223. Pierre Des Maizeaux le cite dans « Some Memoirs », Coll., t. I, p. LXXX. Je laisse de côté la question de savoir si ce texte est compatible avec l'application à Toland de l'épithète "free-thinker " (mot forgé par Toland lui-même dans Adeisidoemon) ou déiste. Déistes ou «penseurs libres ", comme « traduit » le « Doctor 
Une liberté fondamentale, comme l'avait si éloquemment démontré Milton, c'est la liberté de la presse. Dans sa Vie de Milton, Toland écrit : «I need not hesitat to affirm that such a power [de juger ce qui doit ou non être publié] in the hands of any Prince (the licensers being always his creatures) is more dangerous even than a standing army to civil liberty; nor in point of religion is it inferior to the Inquisition. "Une argumentation plus détaillée se trouve en particulier dans A Letter to a Member of Parliament, texte qui est sans doute de Toland (1697 ou $1698^{58}$ ). L'idée essentielle est que l'homme ne doit pas tomber par hasard sur la vérité. Il lui faut comparer les arguments, et donc il faut imprimer dix mille livres à partir des lettres envoyées par les esprits curieux et compétents. Les papistes chez qui la liberté de la presse est restreinte sont ignorants. « Nothing more endears truth to us than that its discovery is the effect of our industry and observation »; «men have the same right to communicate their thought as to think themselves ». La superstition et la dépravation de la religion papiste sont dues à ce qu'on refuse à cette religion la liberté de la presse. S'il n'y avait pas eu la presse, il aurait fallu une seconde révélation. « The freedom or restraint of Press depends on this single question, whether we ought to be free or slaves in our understandings - or in other words, Protestants or Papists. " "The Reformation is wholly owing to the Press. "Qu'on ne redoute pas les écrits profanes et immoraux : ils sont davantage imprimés quand il y a restriction de la presse. Le clergé protestant n'est pas plus innocent que le clergé catholique; il a voulu enchaîner la nation en prêchant la doctrine de l'obéissance absolue. En matière politique comme en matière religieuse, la communication des idées par la presse est un facteur de libération. Attention à ce qu'elle ne soit pas manipulée « to overturn and subvert the very constitution ». Si des hommes courageux, à l'époque de la Révolution, n'avaient pas imprimé «privately» quelques traités pour détromper le peuple, la nation serait encore sous le joug. Et il ne faut pas davantage interdire la publication de découvertes scientifiques sous le prétexte qu'elles ne sont pas en accord avec la religion ${ }^{59}$.

La liberté accroît la conscience et la connaissance; elle en est la condition. C'est ce que montre A Letter Concerning Roman Education en 1727.

Obern » dans Dieu et les hommes (Voltarre, CEuvres. T. 28 : Mélanges, Paris, Garnier, 1879, vol. VII, p. 129-248) sont souvent assimilés aux républicains : dans la liste que donne Voltaire, on trouve Toland, Sidney, Trenchard, Gordon, etc.

58. G. CARABELLI, op. cit. supra n. 4, p. 48-49, indique comme date 1698; mais dans William Cobbett's Parliamentary History of England, Londres, 1809, vol. V, app. XI et XIII, il est noté «printed in the year 1697 ».

59. L.M., p. 23; A Letter to a Member of Parliament, Shewing that a Restraint on the Press Is Inconsistent with the Protestant Religion, and Dangerous to the Liberties of the Nation, 1697, reprod. in William Cobbett's Parliamentary History of England, Londres, 1809, vol. V, app. XIII, p. CXXXI-CXLIX. 
«Where men are restrain'd in their genius, debarr'd all freedom from such and such subjects [...] there 'tis impossible there should be any impartial search after truth, or any real improvement of the understanding, any useful or new discoveries. "C'est seulement l'ignorance des femmes qui les conduit à la superstition (notons au passage ce féminisme que Toland exprime à plusieurs reprises) ${ }^{60}$.

Dans cette perspective, l'éducation et les écoles ont une grande importance : "Princes and States ought to take this matter [...] into their immediate inspection. "Il faudrait réformer les universités; Oxford est " popish, fierce, insociable ", royaliste de surcroît; l'enseignement y est nul. Cambridge est «donquichotesque », et se vante de «turn the Nation as they please ». " $O$ Cambridge! $O$ Oxford! [...] To you we fly for refuge, from you we expect a remedy, 'tis you alone can ally our bigottry and heal our divisions. " Mais, hélas, les universités sont tombées bas; elles renforcent les préjugés. L'électeur palatin projette de rétablir des universités où les jeunes gens de toutes les religions puissent s'instruire ${ }^{61}$.

Mais Toland n'imagine pas pour autant de donner de l'instruction à toutes les classes de la nation. Avec de nombreux whigs, Trenchard par exemple ou Mandeville, Toland s'inquiète des «Charity Schools»: «I think nothing will prove more pernicious to the publick than the new erections of Charity Schools, where the poor children are bred up all pen-men (forsooth) and qualify'd for such employments where they are not wanting, but which are on the contrary more than overstocked. » Cette maudite invention augmente le prix du travail et des marchandises, et encourage les pauvres à la paresse. Et quand on pense à l'argent dépensé par les riches à enseigner le latin à ceux qui n'en feront jamais usage ${ }^{62}$ !

De plus, même s'il ne lui est pas propre, Toland est favorable à un programme populationniste. Tous, sauf exception (Swift), reprennent le mot de Salomon : «Dans la multitude du peuple est l'honneur du roi » (Prov., $14,28)$. Pour Toland, là où il n'y a pas de liberté, il n'y a pas de population. Il constate qu'en Prusse, il n'y a pas beaucoup de population, et donc peu de commerce, parce qu'il n'y a pas de sécurite : "The more people, the more consumtion and commerce, and therefore the more riches, revenues and soldiers. " Et dans la Déclaration de l'électeur palatin, il écrit que l'électeur «ne manquera pas de peupler ses États, en quoi consiste la richesse et la puissance d'un souverain ${ }^{63}$.

60. Coll, t. II, p. $2 ;$ M., p. 188.

61. S.A., p. 69, 73; D.E., p. 19; Mem.M., Coll., t. II, p. 248; M., p. 189 ; Déclaration de l'électeur palatin, en faveur de ses sujets protestants [...] (cité par la suite comme D.E.P.), La Haye, 1707, p. 12.

62. Mem.M., Coll., t. II, p. 250.

63. A.C., p. $22 ;$ D.E.P., p. 12. 
Cependant, à la différence des whigs qui sont pour une naturalisation générale des étrangers, les tories sont « irreconciliable enemies to all foreigners, except [pour des raisons politiques, évidemment] the French ». Ils ont repoussé " the so long desir'd Act for a general naturalization; in the multitude of inhabitants consists the riches and consequently the power of a nation "; les réfugiés français en particulier sont pacifiques, courageux et consomment nos produits ${ }^{64}$.

Une liberté également essentielle à la vie de la nation, ou plutôt des nations, est la liberté de commerce, qui suppose d'ailleurs la liberté de conscience et, en général, la liberté. La liberté est " the true spring of its [de Londres] prodigious trade and commerce with all the known parts of the universe ». On lui doit les colonies d'Amérique, des fabriques en Europe, en Asie et en Afrique. Si, comme on l'a vu, la noblesse est l'âme de l'État, le commerce est «the soul of the British world». L'Angleterre est fière de ses négociants. On sait que plusieurs d'entre eux ont écrit des traités savants, John Cary, Roger Coke, John Houghton. Toland cite The British Merchant, «digested by the ingenious Henry Martin " ${ }^{65}$. Mais le commerce n'est pas toujours, comme il l'est pour Montesquieu par exemple, le doux lien qui se substitue à la guerre; il est souvent accru par la guerre, «which looks like a paradox »; mais nous savons bien que ce n'est pas un paradoxe. Au commerce, Toland oppose le danger de la possession de l'or : la possession de mines d'or et d'argent dans les Indes occidentales a été la ruine de l'industrie, des manufactures, du commerce, de l'agriculture et de la richesse de l'Espagne, « and this in less time than one generation ». Avec l'afflux d'or apparaissent le vice, la paresse, les manières efféminées, la ruine ${ }^{66}$.

Enfin, dans le domaine des relations internationales, et pour répondre en particulier aux problèmes de défense, Toland, avec de nombreux whigs, John Trenchard ${ }^{67}$, Walter Moyle, soutient la «militia» contre les « standing armies ». C'est l'objet du texte The Militia Reform'd. Seuls les hommes libres sont capables de servir dans la « militia». Toutes les tyrannies sont soutenues par des mercenaires. Nos soldats doivent être des «men of property [...] having arms in their hand for the defence of liberty ». Toland dénonce ces parasites « who endeavour to inspire into his

64. R.S., p. 3 ; S.A., p. 55.

65. C'est sans doute l'auteur des Considerations on the East India Trade (1701), opuscule qui décrit de façon frappante et moderne la division du travail. MARX cite plusieurs fois ce texte avec admiration (il en a traduit des extraits dans Le Capital, liv. I, 4e s., chap. 14, II, n.) mais sous le titre de The Advantages of the East India Trade. Il a été réédité par John Ramsay McCulloch, in A Collection of Early English Tracts on Commerce, Londres, 1856.

66. Oceana, «The Dedication », p. II; S.A., p. 43, $58 ;$ P.S., p. 13.

67. Voir Paulette CARrIve, «Le "Caton anglais" John Trenchard", in La Pensée politique anglaise de Hooker à Hume, op. cit. supra n. 23, p. 145. 
[Guillaume] sacred breast an unworthy jealousy of his people, as if he wanted the assistance of a standing army to secure and establish himself that throne which he has already so firmly erected in the hearts and affections of his subjects $»$. Et il porte la même accusation contre les tories dans The Art of Governing. Ce sont des whigs qui ont écrit contre les armées permanentes, "or for making the Fleet and Militia useful ${ }^{68}$.

La politique extérieure doit selon Toland être dominée par l'idée d'équilibre européen, de «balance». Et, bien sûr, cet équilibre doit se faire contre la France menaçante. L'affaire de la succession royale et le problème des alliances sont étroitement liés. Il s'agit d'assurer la liberté contre la tentation française d'une monarchie universelle. Dans Vindicius Liberius, Toland écrit que c'est à partir du principe de la liberté que les whigs ont agi pour la succession de la couronne, et qu'ils l'ont établie « in the Protestant line on the most excellent Sophia and her issue in the House of Hanover, which is no sign they are for a democracy [...], this being the most numerous princely family in Europe ». Et Toland, en 1712, justifie la succession par droit parlementaire et non par droit héréditaire dans $\mathrm{Her}$ Majesty's Reasons for Creating the Electoral Prince of Hannover a Peer of this Realm. Un texte de The Art of Restoring resume bien le propos de Toland: "That the succession of the House of Hanover to the Crown of Great Britain be maintain'd as the only way to fix a real balance of power no less than to preserve all our liberties against universal monarchy. »

Voilà qui distingue whigs et tories : «He's no Whig (let him call himself what he pleases) who any way consents to augment the power or riches of France; nor is the man a Tory in the least who contributes as much as he can to diminish or destroy them."

L'Angleterre se sent responsable de l'équilibre européen. Notre raison d'État à l'exterieur, dit Toland, « is to keep England the head of the Protestant interest in particular, and to hold such an equal balance among foren States in general that none of them grow great enough so to gain on another as that we may com to be losers by it ». Deux buts sont donc à poursuivre : «to keep the balance of Europe equal, or to secure the Protestant religion. » Pour maintenir fixe l'équilibre de l'Europe, nous devons être les arbitres entre l'Empire et la France (ce qui implique des changements d'alliance : les Anglais sont tantôt opposés à l'Autriche, tantôt de son côté contre les Bourbons). Les Paradoxes of State concluent : on ne peut payer trop cher pour la liberté et l'équilibre de l'Europe. La France menace : «The balance of Europe does more effectually preponderate in the scale of France than it came to do by preposterous politics of Oliver Cromwell $\gg{ }^{69}$.

68. M.R., p. 23 ; D.M.P., p. CXVIII; Art, p. 48,$53 ;$ S.A., p. $12,58$.

69. A.L, p. 142 ; V.L., p. $140 ;$ A.L., p. III, VIII; Art, p. 94,142 , 152; P.S., p. $19 ; A . R .$, p. 5 ; aussi S.A., p. 54. 
Toland-Janus? peut-être. On ne peut cependant douter de la sincérité de ses convictions politiques, toutes fondées sur la recherche d'une liberté responsable. Cette liberté ne s'obtient qu'au prix d'un équilibre, équilibre à l'intérieur, assuré par un gouvernement mixte, équilibre de l'Europe assuré par l'hégémonie de l'Angleterre protestante. Si, aujourd'hui, les solutions sont différentes, on ne peut qu'être frappé de la ressemblance des problèmes. Toland, avec d'autres - Trenchard, Sidney, par exemple - inaugure la politique des Lumières.

Paulette CarRIve (juin 1994). 